\title{
COMPARISON OF BIOACTIVITIES OF NATIVE DIATOMACEOUS EARTH AGAINST TURKESTAN COCKROACH [BLATTA LATERALIS WALKER (BLATTODEA: BLATTIDAE)] NYMPHS
}

\author{
ALKAN, M..$^{1 *}$ ATAY, T. ${ }^{2}-$ ERTÜRK, $S .{ }^{1}-$ KEPENEKÇI, I. ${ }^{2}$ \\ ${ }^{1}$ Plant Protection Central Research Institute, 06172 Yenimahalle, Ankara, Turkey \\ ${ }^{2}$ Tokat Gaziosmanpaşa University, Faculty of Agriculture, Department of Plant Protection, \\ Tokat, Turkey \\ ${ }^{*}$ Corresponding author \\ e-mail:alkan0101@gmail.com \\ (Received $7^{\text {th }}$ Feb 2019; accepted $29^{\text {th }}$ Mar 2019)
}

\begin{abstract}
Cockroaches, Blatta lateralis Walker (Orthoptera: Blattidae) have been one of the important groups of insect pests in urban environments. In this study, it was investigated that the effects of different native diatomaceous earths samples against Turkestan cockroach, Blatta lateralis Walker (Blattodea: Blattidae) nymph in the laboratory conditions. For this purpose, three different diatomaceous earths (Turco000, Turca004 and Turco020), obtained from domestic sources, were tested in seven different doses $\left(0.50 \mathrm{~g} / \mathrm{m}^{2}, 0.75 \mathrm{~g} / \mathrm{m}^{2}, 1 \mathrm{~g} / \mathrm{m}^{2}, 1.25 \mathrm{~g} / \mathrm{m}^{2}, 1.50 \mathrm{~g} / \mathrm{m}^{2}, 1.75 \mathrm{~g} / \mathrm{m}^{2}\right.$ and $\left.2.00 \mathrm{~g} / \mathrm{m}^{2}\right)$. It was concluded that the increase in the application dose increased the mortality. Turco020 caused $100 \%$ mortality rate at the end of the $28^{\text {th }}$ hour at the application dose of $1.25 \mathrm{~g} / \mathrm{m}^{2}$. Similarly, the dose of $1.25 \mathrm{~g} / \mathrm{m}^{2}$ of Turco004 and the dose of $0.75 \mathrm{~g} / \mathrm{m}^{2}$ of Turco000 at the same treatment period produced $100 \%$ mortality. Based on the statistical analysis, a positive interaction between particle size and biological activity was detected. These results showed that the diatomite obtained from local sources have an important role in the control of this household pest.
\end{abstract}

Keywords: Turkestan cockroach, bioactivity, native, control, particle size, efficiency, household pest

\section{Introduction}

The Turkestan cockroach, Blatta lateralis Walker (Blattodea: Blattidae), also known as the rusty red cockroach, red runner cockroach or simply rusty red, red runner is native to a large area of the Middle East extending from Libya eastward to Central Asia including Afghanistan, Pakistan, Uzbekistan, and southern Russia (Alesho, 1997). In addition, Kim and Rust (2013) reported that this species has become an important invasive species throughout the southwestern United States. The adults of Turkestan cockroach are three $\mathrm{cm}$ tall and adult females are shorter than male. The Turkestan cockroach females produce between two and 25 ootheca or egg capsules over their life span. Each ootheca contains about 18 eggs. The species becomes adult after five molts, the nymphal developmental period at $26.7^{\circ} \mathrm{C}$ is about $224 \mathrm{~d}$. Five generations of Turkestan cockroaches require about 3 years (Kim and Rust, 2013).

Because of the species cause water and food contamination, transfer pathogens that cause diseases in human to induce allergic reactions and diseases (Shahraki et al., 2013). There is also a risk of damage to common household plants and crops that Turkestan cockroach feeds on once the cockroach reaches pest extents (Kim and Rust, 2013). In addition, Cranshaw (2011) reported that this species was known as a nuisance invader of homes in the United States. The use of insecticides is primarily preferred for 
the control of cockroaches. However, alternative control methods have gained importance due to reasons such as the use of insecticides in indoor areas, threatening human and environmental health and developing resistance of cockroaches to insecticides. Some of the strains have shown resistance to up to 8-12 insecticide (Cochran, 2000; Kambayi et al., 2006).

In this context, there is growing interest in diatomaceous earth, which is known to be particularly effective against indoor pests (Faulde et al., 2006a; Alves et al., 2008; Hosseini et al., 2014; Islam and Rahman, 2016; Akhtar and Isman, 2016; Ertürk et al., 2017; Agnew and Romero, 2017; Atay et al., 2018). The mode of action of DE is generally accepted as desiccation affect on the insects (Faulde et al., 2006b). The effect primarily depends on its physical properties. There are different mechanisms of action such as abrasion of the cuticle, absorption of cuticular waxes, damage to the digestive tract, blockage of the spiracles and tracheae, and surface enlargement combined with dehydration (Ebeling, 1971; Faulde et al., 2006b).

The effectiveness of DEs for killing and controlling insect populations can vary depending on geographical origin, formulation process, oil absorption capacity, and chemical/mechanical modification of DEs, test conditions used and the species being tested (Quarles, 1992; Faulde et al., 2006b). This study was carried out to determine the efficacy of insecticidal activity of DE, which is obtained from domestic sources, against $B$. lateralis nymphs under laboratory conditions.

\section{Material and methods}

\section{Rearing of Blatta lateralis}

Turkestan cockroach nymphs were produced in $30 \mathrm{~L}$ plastic containers with $5 \mathrm{~cm}$ high peat at the base. A mixture of wheat flour and milk powder was used as a nutrient and water-absorbed paper for water needs (Figure 1). The colony was maintained in the climate room at $25 \pm 2{ }^{\circ} \mathrm{C}, 65 \pm 5 \%$ relative humidity and 12:12 (L:D) photoperiod.

\section{Diatomaceous earth}

Diatomaceous earth (DE)'s used in this study were acquired from a local commercial company operating in Ankara-Kazan and Beypazarı counties (Beg-tuğ Mineral). The particle sizes of the diatomaceous earth were ranged 1-10 $\mu \mathrm{m}, 10-30 \mu \mathrm{m}, 43-65 \mu \mathrm{m}$, for Turco000, Turco004 and Turco020, respectively. Local diatomaceous earth mainly composes of $\mathrm{SiO}_{2}(83-95 \%)$ and other minerals were found oxidized form of calcium, aluminum, iron in small amounts.

\section{Bioassay tests}

Turco000, Turco004 and Turco020 local diatomaceous earth were weighed in seven different doses $\left(0.50 \mathrm{~g} / \mathrm{m}^{2}, 0.75 \mathrm{~g} / \mathrm{m}^{2}, 1 \mathrm{~g} / \mathrm{m}^{2}, 1.25 \mathrm{~g} / \mathrm{m}^{2}, 1.50 \mathrm{~g} / \mathrm{m}^{2}, 1.75 \mathrm{~g} / \mathrm{m}^{2}\right.$ and $2.00 \mathrm{~g} / \mathrm{m}^{2}$ ) and added to $20 \mathrm{~cm}^{2}$ glass bottles (Hosseini et al., 2014). Five of Turkestan cockroach nymphs in the same period (60-day-old) were placed into glass bottles. Honey was applied to the inner edges of the bottles to feed of the insects, the mouth of the bottle was covered with insect proof mesh and incubated at $25 \pm 2{ }^{\circ} \mathrm{C}$ and $65 \pm 5 \%$ r.h. conditions. At the end of the fourth, eighth, 12, 16, 20, 24, 28, 32 and 36 hours live and dead insects were counted and recorded. In the experiment, the control group 
weren't treated with the DE. Trials were set up with randomized block design with 18 replications.

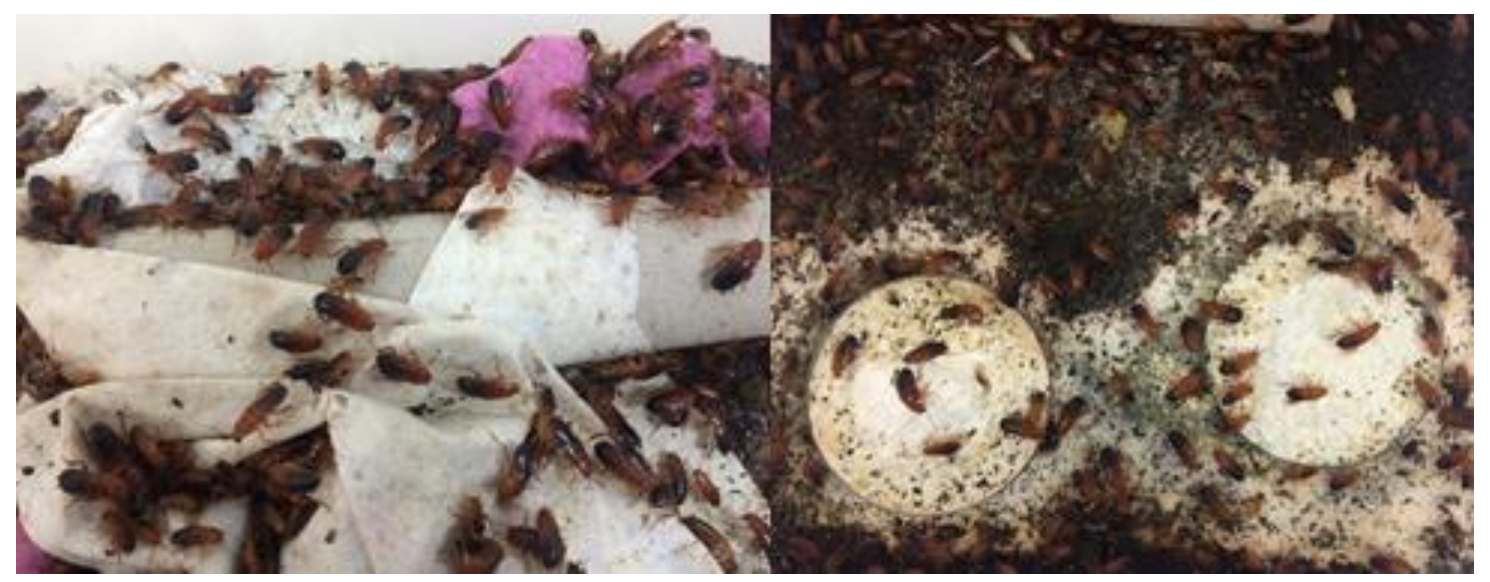

Figure 1. Rearing of Blatta letaralis in laboratory condiditons

\section{Statistical analysis}

Contact toxicity test results were first converted into percent mortality and then were subjected to arcsine $(n \underline{\mathrm{R}}=\arcsin \sqrt{ } n)$ transformation and ANOVA. Variance analysis was carried out with transformed data and additionally, the differences among treatments were analysed by means of Tukey multiple comparison tests $(p<0.05)$. All statistical analyses were conducted with MINITAB ${ }^{\circledR}$ Release 16 package program.

\section{Results}

It was determined that different doses of Turco020 showed activity in varying proportions against Turkestan cockroach nymphs (Table 1).

In all of the studied periods $2.00 \mathrm{~g} / \mathrm{m}^{2}$ showed significant activity on the mortality of the nymphs. After four hours of treatment, the dose of $2.00 \mathrm{~g} / \mathrm{m}^{2}$ had a mortality rate of $72.33 \%$, at the end of the eight hours treatment mortality rate reached $100 \%$. The dose of $1 \mathrm{~g} / \mathrm{m}^{2}$ caused $97.39 \%$ mortality rate at the end of the $24^{\text {th }}$ hours and took place in a different statistical group from the control. All doses showing with significant activity were in a different statistical group than the control group. The doses of $0.50 \mathrm{~g} / \mathrm{m}^{2}, 0.75$ $\mathrm{g} / \mathrm{m}^{2}$ and $1 \mathrm{~g} / \mathrm{m}^{2}$ did not provide $100 \%$ mortality rate in any time period.

Turco004 showed similar bio-activity together with Turco020 on Turkestan cockroach nymphs (Table 2). The lowest dose and the shortest duration time in terms of $100 \%$ mortality were $1.25 \mathrm{~g} / \mathrm{m}^{2}$ dose and 28 hours of treatment, respectively. However, based on the treatment time, $2.00 \mathrm{~g} / \mathrm{m}^{2}$ dose gave $100 \%$ mortality rate at the end of the $12^{\text {th }}$ hour. This dose was statistically different from the control group. The doses of $1.25 \mathrm{~g} / \mathrm{m}^{2}, 1.50 \mathrm{~g} / \mathrm{m}^{2}, 1.75 \mathrm{~g} / \mathrm{m}^{2}$ and $2.00 \mathrm{~g} / \mathrm{m}^{2}$ gave $100 \%$ mortality rate different application time period. 
Table 1. Mortality rates of Turco020 against Turkestan cockroaches

\begin{tabular}{|c|c|c|c|c|c|c|c|c|c|}
\hline \multirow{2}{*}{ HAT } & \multicolumn{9}{|c|}{ Mortality (\%) \pm SE $^{*}$} \\
\hline & Control & $0.50 \mathrm{~g} / \mathrm{m}^{2}$ & $0.75 \mathrm{~g} / \mathrm{m}^{2}$ & $1 g / m^{2}$ & $1.25 \mathrm{~g} / \mathrm{m}^{2}$ & $1.50 \mathrm{~g} / \mathrm{m}^{2}$ & $1.75 \mathrm{~g} / \mathrm{m}^{2}$ & $2.00 \mathrm{~g} / \mathrm{m}^{2}$ & \\
\hline 4 & $0.00 \pm 0.00 \mathrm{c}$ & $0.07 \pm 0.28 \mathrm{c}$ & $1.06 \pm 0.91 \mathrm{c}$ & $0.80 \pm 1.03 \mathrm{c}$ & $4.05 \pm 2.19 \mathrm{c}$ & $4.50 \pm 2.49 \mathrm{c}$ & $23.85 \pm 3.95 b$ & $72.33 \pm 2.75 a$ & $\begin{array}{c}F=27.98, \\
d f=7.143, \\
P<0.05\end{array}$ \\
\hline 8 & $0.00 \pm 0.00 \mathrm{e}$ & $4.14 \pm 1.70 \mathrm{de}$ & $11.50 \pm 1.61 \mathrm{~d}$ & $38.26 \pm 2.28 \mathrm{c}$ & $78.58 \pm 2.02 \mathrm{~b}$ & $90.09 \pm 1.73 b$ & $99.74 \pm 0.53 \mathrm{a}$ & $100.00 \pm 0.00 \mathrm{a}$ & $\begin{array}{c}\mathrm{F}=124.71, \\
\mathrm{df}=7.143, \\
\mathrm{P}<0.05\end{array}$ \\
\hline 12 & $0.00 \pm 0.00 \mathrm{e}$ & $7.04 \pm 1.88 \mathrm{~d}$ & $33.44 \pm 1.27 \mathrm{c}$ & $65.40 \pm 2.04 \mathrm{~b}$ & $98.94 \pm 0.91 \mathrm{a}$ & $99.93 \pm 0.28 \mathrm{a}$ & $100.00 \pm 0.00 \mathrm{a}$ & - & $\begin{array}{c}F=211.62, \\
d f=7.143, \\
P<0.05\end{array}$ \\
\hline 16 & $0.00 \pm 0.00 \mathrm{e}$ & $18.56 \pm 1.73 \mathrm{~d}$ & $41.54 \pm 1.90 \mathrm{c}$ & $79.57 \pm 2.21 \mathrm{~b}$ & $99.93 \pm 0.28 \mathrm{a}$ & $100.00 \pm 0.00 \mathrm{a}$ & - & - & $\begin{array}{c}\mathrm{F}=204.44, \\
\mathrm{df}=7.143, \\
\mathrm{P}<0.05\end{array}$ \\
\hline 20 & $0.07 \pm 0.28 \mathrm{e}$ & $20.61 \pm 1.45 \mathrm{~d}$ & $50.00 \pm 2.61 \mathrm{c}$ & $89.62 \pm 3.10 \mathrm{~b}$ & $99.93 \pm 0.28 \mathrm{a}$ & - & - & - & $\begin{array}{c}\mathrm{F}=153.42, \\
\mathrm{df}=7.143, \\
\mathrm{P}<0.05\end{array}$ \\
\hline 24 & $0.07 \pm 0.28 \mathrm{~d}$ & $22.64 \pm 1.55 \mathrm{c}$ & $58.56 \pm 1.77 \mathrm{~b}$ & $97.39 \pm 2.38 \mathrm{a}$ & $100.00 \pm 0.00 \mathrm{a}$ & - & - & - & $\begin{array}{c}\mathrm{F}=200.31, \\
\mathrm{df}=7.143, \\
\mathrm{P}<0.05\end{array}$ \\
\hline 28 & $0.07 \pm 0.28 \mathrm{~d}$ & $22.64 \pm 1.55 \mathrm{c}$ & $64.55 \pm 2.10 \mathrm{~b}$ & $98.09 \pm 1.81 \mathrm{a}$ & - & - & - & - & $\begin{array}{c}\mathrm{F}=207.85, \\
\mathrm{df}=7.143, \\
\mathrm{P}<0.05\end{array}$ \\
\hline 32 & $0.07 \pm 0.28 \mathrm{~d}$ & $24.53 \pm 1.85 \mathrm{c}$ & $71.23 \pm 2.28 \mathrm{~b}$ & $98.38 \pm 1.46 \mathrm{a}$ & - & - & - & - & $\begin{array}{c}F=199.34, \\
d f=7.143, \\
P<0.05\end{array}$ \\
\hline 36 & $0.07 \pm 0.28 \mathrm{~d}$ & $27.88 \pm 1.50 \mathrm{c}$ & $74.61 \pm 2.64 b$ & $98.38 \pm 1.46 \mathrm{a}$ & - & - & - & - & $\begin{array}{c}\mathrm{F}=194.04, \\
\mathrm{df}=7.143, \\
\mathrm{P}<0.05\end{array}$ \\
\hline
\end{tabular}

*Standard Error; HAT: Hour after treatment; ${ }^{1}$ Different letters in the same line indicate statistically different from each other (Anova $\mathrm{P}<0.05$. Tukey test)

Table 2. Mortality rates of Turco004 against Turkestan cockroaches

\begin{tabular}{|c|c|c|c|c|c|c|c|c|c|}
\hline \multirow{2}{*}{ HAT } & \multicolumn{9}{|c|}{ Mortality (\%) $\pm \mathrm{SE}^{*}$} \\
\hline & Control & $0.50 \mathrm{~g} / \mathrm{m}^{2}$ & $0.75 \mathrm{~g} / \mathrm{m}^{2}$ & $1 g / m^{2}$ & $1.25 \mathrm{~g} / \mathrm{m}^{2}$ & $1.50 \mathrm{~g} / \mathrm{m}^{2}$ & $1.75 \mathrm{~g} / \mathrm{m}^{2}$ & $2.00 \mathrm{~g} / \mathrm{m}^{2}$ & \\
\hline 4 & $0.00 \pm 0.00 \mathrm{~d}^{1}$ & $0.00 \pm 0.00 \mathrm{~d}$ & $0.07 \pm 0.28 \mathrm{~cd}$ & $1.65 \pm 1.06 \mathrm{~cd}$ & $3.66 \pm 1.48 \mathrm{~cd}$ & $5.74 \pm 2.01 \mathrm{c}$ & $23.30 \pm 2.33 b$ & $53.91 \pm 1.91 \mathrm{a}$ & $\begin{array}{c}\mathrm{F}=30.55, \\
\mathrm{df}=7.143, \\
\mathrm{P}<0.05\end{array}$ \\
\hline 8 & $0.00 \pm 0.00 \mathrm{e}$ & $5.79 \pm 1.91 \mathrm{de}$ & $15.53 \pm 2.38 \mathrm{~d}$ & $46.32 \pm 2.70 \mathrm{c}$ & $81.61 \pm 2.24 b$ & $94.21 \pm 1.91 \mathrm{ab}$ & $94.16 \pm 1.51 \mathrm{ab}$ & $98.67 \pm 1.19 \mathrm{a}$ & $\begin{array}{c}\mathrm{F}=74.51, \\
\mathrm{df}=7.143, \\
\mathrm{P}<0.05\end{array}$ \\
\hline 12 & $0.00 \pm 0.00 \mathrm{~d}$ & $13.95 \pm 1.97 \mathrm{c}$ & $45.10 \pm 3.03 \mathrm{~b}$ & $66.99 \pm 2.57 \mathrm{~b}$ & $95.31 \pm 1.51 \mathrm{a}$ & $98.02 \pm 1.32 \mathrm{a}$ & $98.94 \pm 0.91 \mathrm{a}$ & $100.00 \pm 0.00 \mathrm{a}$ & $\begin{array}{c}\mathrm{F}=95.54, \\
\mathrm{df}=7.143, \\
\mathrm{P}<0.05\end{array}$ \\
\hline 16 & $0.00 \pm 0.00 \mathrm{e}$ & $21.42 \pm 2.02 \mathrm{~d}$ & $61.09 \pm 3.33 \mathrm{c}$ & $86.89 \pm 1.86 \mathrm{~b}$ & $99.40 \pm 0.74 \mathrm{a}$ & $99.93 \pm 0.28 \mathrm{a}$ & $100.00 \pm 0.00 \mathrm{a}$ & - & $\begin{array}{c}\mathrm{F}=138.81, \\
\mathrm{df}=7.143, \\
\mathrm{P}<0.05\end{array}$ \\
\hline 20 & $0.00 \pm 0.00 \mathrm{e}$ & $32.28 \pm 1.84 \mathrm{~d}$ & $72.33 \pm 2.27 \mathrm{c}$ & $92.31 \pm 2.06 \mathrm{~b}$ & $99.74 \pm 0.53 \mathrm{a}$ & $100.00 \pm 0.00 \mathrm{a}$ & - & - & $\begin{array}{c}\mathrm{F}=163.61, \\
\mathrm{df}=7.143, \\
\mathrm{P}<0.05\end{array}$ \\
\hline 24 & $0.00 \pm 0.00 \mathrm{e}$ & $37.82 \pm 2.26 \mathrm{~d}$ & $76.42 \pm 1.95 c$ & $95.31 \pm 1.51 \mathrm{~b}$ & $99.93 \pm 0.28 \mathrm{a}$ & - & - & - & $\begin{array}{c}F=180.24, \\
d f=7.143, \\
P<0.05\end{array}$ \\
\hline 28 & $0.00 \pm 0.00 \mathrm{~d}$ & $40.34 \pm 1.72 \mathrm{c}$ & $77.46 \pm 1.91 \mathrm{~b}$ & $98.02 \pm 1.32 \mathrm{a}$ & $100.00 \pm 0.00 \mathrm{a}$ & - & - & - & $\begin{array}{c}F=221.59, \\
d f=7.143, \\
P<0.05\end{array}$ \\
\hline 32 & $0.00 \pm 0.00 \mathrm{~d}$ & $41.54 \pm 1.65 \mathrm{c}$ & $84.38 \pm 1.98 b$ & $98.94 \pm 0.92 \mathrm{a}$ & - & - & - & - & $\begin{array}{c}F=240.78, \\
d f=7.143, \\
P<0.05\end{array}$ \\
\hline 36 & $0.00 \pm 0.00 \mathrm{~d}$ & $42.76 \pm 1.82 \mathrm{c}$ & $86.96 \pm 1.96 b$ & $99.73 \pm 0.53 \mathrm{a}$ & - & - & - & - & $\begin{array}{c}\mathrm{F}=255.58, \\
\mathrm{df}=7.143, \\
\mathrm{P}<0.05\end{array}$ \\
\hline
\end{tabular}

*Standard Error; HAT: Hour after treatment; ${ }^{1}$ Different letters in the same line indicate statistically different from each other (ANOVA $\mathrm{P}<0.05$ Tukey test) 
Turco 000 having the smallest particle size, showed that dose-dependent activity in varying proportions. In terms of the highest activity and the shortest application time, the dose of $0.75 \mathrm{~g} / \mathrm{m}^{2}$ provided $100 \%$ mortality at the end of the $28^{\text {th }}$ hours. Besides, at the end of $12^{\text {th }}$ hours, complete mortality was obtained at doses of $1.25 \mathrm{~g} / \mathrm{m}^{2}$ and above (Table 3). All doses and times showing significant bioactivity were in a different statistical group with the control group.

Table 3. Toxicity of Turco 000 against Turkestan cockroaches

\begin{tabular}{|c|c|c|c|c|c|c|c|c|c|}
\hline \multirow{2}{*}{ HAT } & \multicolumn{9}{|c|}{ Mortality (\%) $\pm \mathrm{SE}^{*}$} \\
\hline & Control & $0.50 \mathrm{~g} / \mathrm{m}^{2}$ & $0.75 \mathrm{~g} / \mathrm{m}^{2}$ & $1 \mathrm{~g} / \mathrm{m}^{2}$ & $1.25 \mathrm{~g} / \mathrm{m}^{2}$ & $1.50 \mathrm{~g} / \mathrm{m}^{2}$ & $1.75 \mathrm{~g} / \mathrm{m}^{2}$ & $2.00 \mathrm{~g} / \mathrm{m}^{2}$ & \\
\hline 4 & $0.00 \pm 0.00 \mathrm{c}^{1}$ & $0.14 \pm 0.61 \mathrm{c}$ & $1.65 \pm 1.06 \mathrm{c}$ & $0.80 \pm 1.03 \mathrm{c}$ & $3.22 \pm 1.25 b c$ & $3.66 \pm 1.48 \mathrm{bc}$ & $16.53 \pm 2.08 \mathrm{ab}$ & $19.18 \pm 2.52 \mathrm{ab}$ & $\begin{array}{c}\mathrm{F}=9.19, \\
\mathrm{df}=7.143, \\
\mathrm{P}<0.05\end{array}$ \\
\hline 8 & $0.00 \pm 0.00 \mathrm{e}$ & $27.97 \pm 1.63 \mathrm{~d}$ & $64.12 \pm 1.83 \mathrm{c}$ & $77.55 \pm 2.08 \mathrm{c}$ & $83.39 \pm 1.67 b c$ & $94.88 \pm 2.21 \mathrm{ab}$ & $96.34 \pm 1.48 \mathrm{ab}$ & $99.40 \pm 0.74 \mathrm{a}$ & $\begin{array}{c}\mathrm{F}=70.41, \\
\mathrm{df}=7.143, \\
\mathrm{P}<0.05\end{array}$ \\
\hline 12 & $0.00 \pm 0.00 \mathrm{~d}$ & $48.77 \pm 1.14 \mathrm{c}$ & $96.83 \pm 1.65 b$ & $99.73 \pm 0.53 \mathrm{ab}$ & $100.00 \pm 0.00 \mathrm{a}$ & $100.00 \pm 0.00 \mathrm{a}$ & $100.00 \pm 0.00 \mathrm{a}$ & $100.00 \pm 0.00 \mathrm{a}$ & $\begin{array}{c}\mathrm{F}=329.37, \\
\mathrm{df}=7.143, \\
\mathrm{P}<0.05\end{array}$ \\
\hline 16 & $0.00 \pm 0.00 \mathrm{c}$ & $60.76 \pm 1.67 \mathrm{~b}$ & $99.40 \pm 0.74 \mathrm{a}$ & $100.00 \pm 0.00 \mathrm{a}$ & - & - & - & - & $\begin{array}{c}\mathrm{F}=446.07, \\
\mathrm{df}=7.143, \\
\mathrm{P}<0.05\end{array}$ \\
\hline 20 & $0.00 \pm 0.00 \mathrm{c}$ & $76.53 \pm 2.12 b$ & $99.93 \pm 0.28 \mathrm{a}$ & - & - & - & - & - & $\begin{array}{c}\mathrm{F}=426.91, \\
\mathrm{df}=7.143, \\
\mathrm{P}<0.05\end{array}$ \\
\hline 24 & $0.00 \pm 0.00 \mathrm{c}$ & $77.47 \pm 1.97 \mathrm{~b}$ & $99.93 \pm 0.28 \mathrm{a}$ & - & - & - & - & - & $\begin{array}{c}\mathrm{F}=455.25, \\
\mathrm{df}=7.143, \\
\mathrm{P}<0.05\end{array}$ \\
\hline 28 & $0.00 \pm 0.00 \mathrm{c}$ & $88.58 \pm 2.01 \mathrm{~b}$ & $100.00 \pm 0.00 \mathrm{a}$ & - & - & - & - & - & $\begin{array}{c}F=497.8, \\
d f=7.143, \\
P<0.05\end{array}$ \\
\hline 32 & $0.00 \pm 0.00 \mathrm{c}$ & $91.64 \pm 2.22 \mathrm{~b}$ & - & - & - & - & - & - & $\begin{array}{c}\mathrm{F}=447.41, \\
\mathrm{df}=7.143, \\
\mathrm{P}<0.05\end{array}$ \\
\hline 36 & $0.00 \pm 0.00 \mathrm{c}$ & $95.91 \pm 2.10 \mathrm{~b}$ & - & - & - & - & - & - & $\begin{array}{c}\mathrm{F}=474.63, \\
\mathrm{df}=7.143, \\
\mathrm{P}<0.05\end{array}$ \\
\hline
\end{tabular}

*Standart Error; HAT: Hour after treatment; ${ }^{1}$ Different letters in the same line indicate statistically different from each other (Anova $\mathrm{P}<0.05$. Tukey test

Statistical analysis showed that there was a significant interaction between diatomaceous earth*dose and diatomaceous earth*time. Interactions of dose, time, and diatoms, both individually and with each other, were found to be statistically significant (Table 4).

Table 4. ANOVA parameters for main effects and interactions for mortality of Turkestan cockroach

\begin{tabular}{c|c|c|c|c|c|c}
\hline Source & DF & Seq SS & Adj SS & Adj MS & F & P \\
\hline Diatomaceous earth & 2 & 4830 & 2959 & 1480 & 10.45 & 0.00 \\
Doses & 6 & 178891 & 49931 & 8322 & 58.78 & 0.00 \\
Time & 8 & 1318661 & 1034576 & 129322 & 913.5 & 0.00 \\
Diatomaceous earth * Dose & 12 & 39469 & 6830 & 569 & 4.02 & 0.00 \\
Diatomaceous earth * Time & 16 & 110531 & 55313 & 3457 & 24.42 & 0.00 \\
Dose * Time & 48 & 496830 & 443475 & 9239 & 65.26 \\
Diatomaceous earth * Dose * Time & 96 & 536729 & 536729 & 5591 & 39.49 & 0.00 \\
Error & 3213 & 454856 & 454856 & 142 & & \\
Total & 3401 & 3140798 & & & \\
\hline
\end{tabular}




\section{Discussion}

In this study was tested the effectiveness of the native diatomaceous earth, which is a biorational control method, for the Turkestan cockroach nymphs that are important indoor and outdoor pest, in terms of an alternative control method to the chemical compounds. In the trials, the insecticidal properties of local diatomaceous earth were initially tested in different doses and times against Turkestan cockroach nymphs and in this aspect, this study is a first in literature. Results from contact bioassays revealed that nymphs of the Turkestan cockroachs are sensitive to the diatomaceous earth at different rates. The most toxic formulation was Turco000 with the highest mortality rate and minimum exposure time (Table 3). It is known that the effect of the particle size on the effectiveness against insects is significant; smaller particles are significantly more effective than larger ones (Korunic et al., 2011). Similarly, Turco004 and Turco020 were less effective because of the having larger particle size than Turco000. The results we found supporting Bhan et al. (2014) findings showed that developed temephos and imidacloprid containing polyethylene glycol encapsulated nanopesticide with the meltdispersion method and find more active against larvae of Culex quinquefasciatus (Diptera: Culicidae).

It is generally known for the diatomaceous earth that high relative humidity content effects the rate of mortality due to the desiccation (Fields, 1998; Subramanyam and Roesli, 2000; Fields and Korunic, 2000; Mewis and Ulrichs, 2001; Athanassiou et al., 2011; Frederick and Subramanyam, 2016). In our study, we used $65 \pm 5 \%$ r.h. conditions in terms of determining the effect of the r.h. for the toxicity test. However, this relative humidity value needs to be diversified in future studies. Faulde et al. (2006a) revealed that seven kinds of DE formulation have been showing different toxicity at $25 \mathrm{~g}$ DE powder per $\mathrm{m}^{2}$ to the adults of German cockroach, Blattella germanica (L.) (Orthoptera: Blattellidae) in a humid climate ( $85 \%$ r.h.), complete populations were eliminated within 10 days with FS 90.0S White, FS 90.0S, and FS 95.0 DE formulations tested. Our findings showed that the doses of $1 \mathrm{~g} / \mathrm{m}^{2}$ of Turco000 killed the Turkestan cockroach nymphs at the end of the $16^{\text {th }}$ hour's treatment. It is estimated that morphological differences of different types of cockroaches and the origin of the diatomaceous affects the mortality rates of insects at several rates.

The reactions of biological stages of insects to diatomaceous earth are also different. It is known that larval or nymphal stages of insect more susceptible to the DE formulations. Older larvae or nymph stages are significantly more resistant than young larval periods (Vayias and Athanassiou, 2004). Although the adult cockroach was not used in this study, it can be said that the nymphal periods of Turkestan cockroach are more sensitive to diatomaceous earth. Similarly, Hosseini et al. (2014) reported that the dose of $25 \mathrm{~g} / \mathrm{m}^{2}$ of DE completely kills the nymphal stages of German cockroaches at 72 hours, while $\mathrm{LC}_{50}$ and $\mathrm{LC}_{90}$ values for adults determined as a $12.9034 \mathrm{~g} / \mathrm{m}^{2}$ and $626.0942 \mathrm{~g} / \mathrm{m}^{2}$, respectively. Vayias and Athanassiou (2004) stated that all larvae of Tribolium castaneum Herbst, 1797 (Coleoptera: Tenebrionidae) were killed at the dose of $1.5 \mathrm{~g} / \mathrm{kg}$ of SilicoSec whereas this rate was $50 \%$ in adults after 48 hours exposure period.

As a result, cockroaches emerge as a problem in terms of hygiene in areas where human activity and habitats are intense. Cockroaches are the potential carrier of human diseases, a pathogenic organism such as bacteria, protozoa, fungi, and helminths (Tatfeng et al., 2005; Baumholtz et al., 2008). In addition, increased awareness of side effect of the synthetic pesticides to the society, the resistance statues of insects against 
pesticides, has also led to the need to investigate safe control methods for the cockroaches that can be used in the integrated pest management system.

\section{Conclusions}

Diatomaceous earth can be regarded, as have strongly insecticidal properties against Turkestan cockroach. The results show that there is a negative correlation between particle size and activity. In view of these findings, native diatomaceous earth should be investigated in different humidity and temperature conditions against an invasive species Turkestan cockroach adults and nymphs.

\section{REFERENCES}

[1] Agnew, J., Romero, A. (2017): Behavioral responses of the common bed bug, Cimex lectularius, to insecticide dusts. - Insects 8(3): 83.

[2] Akhtar, Y., Isman, M. B. (2016): Efficacy of diatomaceous earth and a DE-aerosol formulation against the common bed bug, Cimex lectularius Linnaeus in the laboratory. Journal of pest science 89(4): 1013-1021.

[3] Alesho, N. A. (1997): Synathropic cockroaches of Russia. - Proc. Inter. Coll. Social Insects 34: 45-50.

[4] Alves, L. F., Oliveira, D. G., Neves, P. M. (2008): Factors affecting diatomaceous earth effectiveness in the control of Alphitobius diaperinus (Panzer) (Coleoptera: Tenebrionidae) adults. - Neotrop Entomol 37(6): 716-722.

[5] Atay, T., Akın, A., Alkan, M., Ertürk, S. (2018): Pre-Studies on Contact Toxicity of Some Local Diatomaceous Earths on Mealworm, Tenebrio molitor L. (Coleoptera:Tenebrionidae), Larvae. - I. International Agricultural Science Congress, 0912 May 2018, Van/Turkey, p494.

[6] Athanassiou, C. G., Kavallieratos, N. G., Vayias, B. J., Tomanovic, Z., Petrovic, A., Rozman, V., Adler, C., Korunic, Z., Milovanovic, D. (2011): Laboratory evaluation of diatomaceous earth deposits mined from several locations in central and southeastern Europe as potential protectants against coleopteran grain pests. - Crop Prot. 30: 329-339.

[7] Baumholtz, M. A., Parish, L. C., Witkowski, J. A., Nutting, W. B. (2008): The medical importance of cockroaches. - Int J Dermatol. 36: 90-6.

[8] Bhan, S., Mohan, L., Srivastava, C. N. (2014): Relative larvicidal potentiality of nanoencapsulated Temephos and Imidacloprid against Culex quinquefasciatus. - Journal of Asia-Pacific Entomology 17(4): 787-791.

[9] Cochran, D. G. (2000): Cockroach: their biology, distribution, and control. WHO/CDS/CPC/ WHO st ed, 2000. http://www.who.int/iris/handle/10665/65846.

[10] Cranshaw, W. (2011): A review of nuisance invader household pests of the United States. - American Entomologist 57(3): 165-169.

[11] Ebeling, W. (1971): Sorptive dusts for pest control. - Annu Rev Entomol. 16: 123-158.

[12] Ertürk, S., Ferizli, A. G., Emekci, M. (2017): Depolanmış çeltikte pirinç biti, Sitophilus oryzae L., 1763 (Coleoptera: Curculionidae)'nin mücadelesinde diyatom toprağ 1 formülasyonlarının değerlendirilmesi. - Türkiye Entomoloji Dergisi 41(3): 347-354.

[13] Faulde, M. K., Tisch, M., Scharninghausen, J. J. (2006a): Efficacy of modified diatomaceous earth on different cockroach species (Orthoptera, Blattellidae) and silverfish (Thysanura, Lepismatidae). - J Pest Sci. 79: 155-161.

[14] Faulde, M. K., Scharninghausen, J. J., Cavaljug, S. (2006b): Toxic and behavioural effects of different modified diatomaceous earths on the German cockroach, Blattella germanica (L.) (Orthoptera: Blattellidae) under simulated field conditions. - Journal of Stored Products Research 42: 253-263. 
[15] Fields, P. (1998): Diatomaceous earth: advantages and limitations. - In: Zuxun, J., Quan, L., Yongsheng, L., Xianchang, T., Lianghua, G. (eds.) Proceedings of the seventh international working conference of stored products protection. Sichuan Publishing House of Science \& Technology, Peoples Republic of China. I, pp 781-789.

[16] Fields, P., Korunic, Z. (2000): The effect of grain moisture content and temperature on the efficacy of diatomaceous earths from different geographical locations against storedproduct beetles. - J Stored Prod Res. 36: 113.

[17] Frederick, J. L., Subramanyam, B. (2016): Influence of temperature and application rate on efficacy of a diatomaceous earth formulation against Tribolium castaneum adults. Journal of Stored Products Research 69: 86-90.

[18] Hosseini, S. A., Bazrafkan, S., Vatandoost, H., Abaei, M. R., Ahmadi, M. S., Tavassoli, M., Shayeghi, M. (2014): The insecticidal effect of diatomaceous earth against adults and nymphs of Blattella germanica. - Asian Pacific journal of tropical biomedicine 4: 228232.

[19] Islam, M. S., Rahman, M. M. (2016): Diatomaceous earthinduced alterations in the reproductive attributes in the housefly Musca domestica L. (Diptera: Culicidae). - Elixir Appl. Zool 2(5).

[20] Kamyabi, F., Vatan Doost, H., Abolhassani, M., Aghasi, M., Telmadarehei, Z., Abaei, M. R. (2006): Susceptibility of different strains of German cockroach, (B. Germanica) to three insecticides in hospitals affiliated to Kerman University of Medical Sciences. Journal of Mazandaran University of Medical Sciences 16: 108-98.

[21] Kim, T., Rust, M. K. (2013): Life history and biology of the invasive Turkestan cockroach (Dictyoptera: Blattidae). - Journal of economic entomology 106(6): 24282432.

[22] Korunic, Z., Rozman, V., Halamic, J., Kalinovic, I., Hamel, D. (2011): Insecticide potential of diatomaceous earth from Croatia. - IOBC-WPRS Bulletin 69: 389-397.

[23] Mewis, I., Ulrichs, C. H. (2001): Action of amorphous diatomaceous earth against different stages of the stored product pests Tribolium confusum, Tenebrio molitor, Sitophilus granarius and Plodia interpunctella. - J Stored Prod Res. 37: 153-164.

[24] Quarles, W. (1992): Diatomaceous earth for pest control. - The IPM Practitioner 14(5/6): $1-11$.

[25] Shahraki, G. H., Parhizkar, S., Nejad, A. R. S. (2013): Cockroach Infestation and Factors Affecting the Estimation of Cockroach Population in Urban Communities. - International Journal of Zoology 2013: 1-6.

[26] Subramanyam, B. H., Roesli, R. (2000): Inert dusts. - In: Subramanyam, B. H., Hagstrum, D. W. (eds.) Alternatives to pesticides in stored-product IPM. Dordrecht: Kluwer Academic Publishers. p. 321-373.

[27] Tatfeng, Y. M., Usuanlel, M. U., Orukpe, A., Digban, A. K., Okodua, M., Oviasogie, F. (2005): Mechanical transmission of pathogenic organisms: the role of cockroaches. - J Vect Born Dis. 42: 129-34.

[28] Vayias, B. J., Athanassiou, C. G. (2004): Factors affecting the insecticidal efficacy of the diatomaceous earth formulation Silico-Sec against adults and larvae of the confused flour beetle, Tribolium confusum Du Val (Coleoptera: Tenebrionidae). - Crop Protection 23: 565-573. 